Current Issues of Education and Science, 2021

Conference proceedings. ISBN: 978-617-7089-14-7

https://doi.org/10.26697/9786177089147.2021

PSYCHOLOGY

DOI: $\underline{\text { https://doi.org/10.26697/9786177089147.2021.07 }}$

\title{
Psychological Transformation Game "My Dao" as an Effective Method of Psychologist Practice
}

\author{
Yuriy B. MELNYK ${ }^{1,2}$ (D), Anatoliy V. STADNIK ${ }^{1,2,3,4}$ (i) \\ ${ }^{I}$ Kharkiv Regional Public Organization "Culture of Health" \\ (KRPOCH), Ukraine \\ ${ }^{2}$ Scientific Research Institute KRPOCH, Ukraine \\ ${ }^{3}$ Social-Psychological Center KRPOCH, Ukraine \\ ${ }^{4}$ Kharkiv National University of Internal Affairs, Ukraine
}

Corresponding Author Details

Yuriy B. MELNYK, ybm.office@gmail.com

Received: 17.08.2021; Accepted: 27.09.2021; Published: 17.12.2021

\section{Brief Summary}

Background: Psychologists should have a wide arsenal of modern effective methods of psychological practice. Psychological transformation games are becoming more and more popular, with great potential for solving a wide range of problems related to clients' mental health.

The aim of the study: To explore the effectiveness of the author's methodology of psychological transformation game "My Dao" according to Schwartz's model of value orientations.

Methods: The study participants were 134 people, including 75 men and 59 women aged 17-35 years. The control group consisted of 126 people, including 69 men and 57 women aged 18-30 years. Values for the study and control groups were calculated using the SPSS Statistics module. The obtained results prove statistical significance $(p<0.05)$.

Results: The greatest significance of the influence of the author's game on the participants is observed at the level of normative ideals: tradition, conformity, security, hedonism and universalism. This indicates a certain change in it towards an increase in harmony and stability, as well as a decrease in humility, acceptance of one's destiny. At the level of 
individual priorities, there is an increase in hedonism, power and stimulation, which indicates an increase in the role of pleasure, academic achievement, ambition, desire for novelty and deep experience. The obtained high rates of universalism, hedonism, independence and conformity indicate an increase in understanding, tolerance, pleasure in life, self-control, self-management, self-discipline and politeness among the participants in the game.

Conclusions: The use of the transformational game "My Dao" in psychological practice is an effective psychotherapeutic method that affects the participants' value orientations, changes in self-esteem and motivation, the disclosure of their personal resources for problem solving and further development.

\section{Keywords:}

psychological transformational game, value orientations, motivation, diagnostics, tools, psychological problems.

\section{Психологічна трансформаційна гра "Мy Dao" як ефективний метод роботи психолога}

\section{Юрій Б. МЕЛЬНИК ${ }^{1,2}$ (D), Анатолій В. СТАДНІК ${ }^{1,2,3,4}$}

${ }^{1}$ Харківська обласна громадська організачія “Культура Здоров'я” (ХОГОКЗ), Украйна

${ }^{2}$ Науково-дослідний інститут ХОГОКЗ, Украӥна

${ }^{3}$ Сочіально-психологічний центр ХОГОКЗ, Украӥна

${ }^{4}$ Харківський національний університет внутрішніх справ, Україна

\section{Деталі Автора-Кореспондента:}

Юрій Б. МЕЛЬНИК, ybm.office@gmail.com

\section{Анотація}

Bступ: Психологи мають володіти широким арсеналом сучасних ефективних методів психологічної практики. Все більш затребуваними стають психологічні трансформаційні ігри, які мають великий потенціал щуодо розв'язання широкого кола проблем, пов'язаних з психічним здоров'ям клієнтів.

Мета дослідження: Дослідити ефективність авторської методики психологічної трансформачійної гри “Му Daо” за діагностикою иіннісних орієнтацій Швария.

Методи: Учасниками дослідження були 134 особи, серед них 75 чоловіків та 59 жінок віком 17-35 років. Контрольну групу склали 126 
особи, серед них 69 чоловіків та 57 жінок віком 18-30 років. 3 а допомогою модуля SPSS Statistics здійснювались розрахунки значень для досліджуваної $i$ контрольної груп. Отримані результати доводять статистичну значимість $(p<0.05)$.

Результати: Найбільша значущість впливу авторської гри на учасників спостерігається на рівні нормативних ідеалів: традииіï, конформності, безпеки, гедонізму та універсалізму. Це свідчить про певну зміну їх у бік збільшення гармонії $i$ стабільності, а також зменшення смиренності, прийняття своєї долі. На рівні індивідуальних пріоритетів спостерігається збільшення гедонізму, влади та стимуляиії, що вказує на зростання ролі задоволення, успішності, амбітності, прагнення до новизни та глибоких пережсивань. Отримані високі показники універсалізму, гедонізму, самостійності та конформності вказують на зростання розуміння, терпимості, насолоди життям, самоконтролю, самоврядування, самодисципліни та ввічливості в учасників гри.

Висновки: Використання в психологічній практиці трансформачійної гри "Му Dао” є ефективним психотерапевтичним методом, який впливає на иіннісні орієнтації учасників, зміну самооиінки і мотивації, розкриття їхніх особистісних ресурсів для вирішення проблем і подальшого розвитку. Ця методика є достатньо універсальною за віковою категорією учасників $i$ за можливістю вирішення психологічних проблем.

\section{Ключові слова:}

психологічна трансформаційна гра, ијіннісні орієнтації, мотивачія, діагностика, інструментарій, психологічні проблеми.

Важливо не те, чого Ви досягли у своєму житті або що залишили після себе важливо, як Ви жили (Yu. B. Melnyk).

\section{Вступ:}

Iз розповсюдженням пандемії COVID-19 у багатьох країнах запроваджене соціальне дистанціювання, що впливає на психоемоційний стан населення та сприяє проявам девіантної поведінки, невротичним розладам тощо. Все це підвищує попит на психологічну допомогу та актуалізуе психопрофілактичні та психогігієнічні заходи серед різних верств населення (Melnyk, Stadnik, \& Pypenko, 2020).

Серед широкого кола психологічних підходів, а також методів, які в них використовуються, розглянемо один 3 найбільш 
універсальних, на нашу думку - метод психологічної гри. Психологічна гра, на відміну від “розважальної гри” або “освітньої гри”, що зосереджені переважно на відпочинку або навчанні (інтелектуальному розвитку), здійснює вплив на всі сфери життєдіяльності особистості: мотиваційну, когнітивну, афективну, канативну, ціннісну, а також сприяє покращенню психічного здоров'я особистості в цілому (Melnyk, 2004).

Останнім часом серед психологів та психотерапевтів все більш затребуваними є психологічні трансформаційні ігри, оскільки вони як прямо, так i опосередковано вирішують широке коло проблем, пов'язаних $з$ психічним здоров'ям їхніх клієнтів. Зокрема розвивають пізнавальну активність, емоційний інтелект, соматичне усвідомлення та архетипічну інтеграцію, ціннісні орієнтації, чим сприяють психологічно значущим особистим трансформаціям.

Отже, для психолога ігрова форма діяльності є універсальною і привабливою, вона моделює проживання важких ситуацій та їх розв'язання. Тому в сучасній психологічній практиці активно використовуються трансформаційні ігри.

Мета дослідження. Дослідити ефективність авторської методики психологічної трансформаційної гри "Му Dao" Ю. Мельника, А. Стадніка за методикою діагностики ціннісних орієнтацій Ш. Шварца.

\section{Методи:}

У дослідженні використано інструментарій психологічної трансформаційної гри “Мy Dao” (Melnyk \& Stadnik, 2018b). Методика діагностики ціннісних орієнтацій Ш. Шварца (адаптація В. Карандашева) (Karandashev, 2004) використовувалась для перевірки ефективності впливу розробленої методики психологічної трансформаційної гри “Му Dао” на учасників дослідження.

В дослідженні взяли участь 134 особи, серед них 75 чоловіків (55.97\%) та 59 жінок (44.03\%) віком 17-35 років. Контрольну групу склали 126 особи, серед них 69 чоловіків (54.76\%) та 57 жінок (45.24\%) віком 18-30 років.

Використовувались методи математичної статистики - критерій Пірсона $\left(\chi^{2}\right)$. За допомогою модуля SPSS Statistics здійснювались розрахунки середніх значень цінностей особистості досліджуваної i контрольної груп. Отримані результати доводять статистичну значимість $(\mathrm{p}<0.05)$. 


\section{Результати:}

Одним з ефективних методів у роботі психолога $є$ психологічна гра. При цьому за формою та змістом вона, як правило, зрозуміла i цікава широким колам населення будь-якого рівня підготовки. Завдяки цим особливостям психологічна гра може бути сучасним, технологічним і універсальним інструментом психологічної допомоги.

Гра $є$ універсальним феноменом людського буття, властивим всім без винятку людським співтовариствам. В аналізі феномена гри сучасна наука спирається на історично сформовані підходи в теорії гри попередніх епох, кожна 3 яких характеризується власними поглядами на їі сутність (Guzik, 2012).

Найбільший внесок в сучасне наукове розуміння і тлумачення феномена гри внесли Berne (1964/2016); Fink (2016); Huizinga (1938/2016).

Людська культура виникає i розгортається в грі. Культура виникає у формі гри, спочатку вона розігрується i тим самим закріплюється в житті суспільства, передається від покоління до покоління (Huizinga (1938/2016).

Гра - це комплекс прихованих транзакцій, що повторюються i характеризуються чітко визначеним психологічним виразом. Під час прихованої транзакції учасник найчастіше прикидається, оскільки створює видимість, що робить щось одне, а в дійсності робить зовсім інше. У загальному плані ігри є нескінченним і динамічним елементом несвідомого плану або сценарію життя кожної людини (Berne, 1964/2016).

Fink (2016) називає гру п'ятим з основних феноменів людського існування, останнім в ієрархічному сенсі, менш значним і вагомим, ніж смерть, праця, панування та любов. Для нього гра настільки ж відвічна, як і ці феномени. Вона охоплює все людське життя до самої підстави, опановує нею і істотним чином визначає буттєвий склад людини, а також спосіб розуміння буття людиною. Вона пронизує інші основні феномени людського існування, будучи нерозривно переплетеною і скріпленою з ними.

На певному етапі розвитку суспільства ігрові практики все більш явно проявляються в неігрових контекстах, а ігрова логіка починає цілеспрямовано використовуватися для вирішення певних завдань, зокрема ділових, управлінських та навчальних. В сучасній науці ці процеси описуються терміном “іграїзація" або “гейміфікація" (Frissen et al., 2015).

Nicholson (2015) пропонує модель “значущої гейміфікації RECIPE” для трансформативного довгострокового впливу на 
поведінку клієнтів, засновану на внутрішній мотивації. В рамках сформованої системи суспільних відносин гра виступає одним 3 механізмів передачі культурних традицій від одного покоління до іншого (Nicholson, 2015). Багато дитячих ігор, в ході яких відбувається соціалізація дитини, $є$ імітацію самих різних дій, здійснюваних людьми в реально-життєвих ситуаціях. Гра може бути імітацією конфлікту. Переживши конфлікт в ігровій формі, людина виявляється підготовленою до дій у разі його реального розгортання.

За сучасними поглядами гра - це відображення реальності, моделювання проживання важких ситуацій. А ділова гра виступає як засіб і метод підготовки і адаптації до трудової діяльності, соціальних контактів в професійних ситуаціях.

Сучасною формою роботи психолога $є$ трансформаційна гра (Faerman, 2020). Ігрова технологія використовується як універсальний і привабливий вид діяльності і пізнання, форма і методика навчання. Ігрова діяльність виконує такі основні функції (Cherevko, 2006): розважальну (надання задоволення, пробудження інтересу, надихання до подальшої діяльності); комунікативну (навчання міжособистісному спілкуванню, засвоєння соціально-культурних цінностей); самореалізації (це полігон практичної діяльності); терапевтичну (подолання різних труднощів, що виникають в інших видах життєдіяльності); діагностичну (виявлення відхилень від нормативної поведінки, самопізнання в процесі гри); коригувальну (внесення позитивних змін в структуру особистісних якостей); соціалізаційну (включення в систему суспільних відносин, засвоєння норм людського співіснування).

3'ясовано, що трансформаційні ігри мають потужний мотивувальний потенціал (Heckhausen, 1977). Дієвість трансформаційної гри забезпечується "ефектом Зейгарника" (ефект незавершеної дії та ефект очікування), який може викликати відчуття наближення успіху в досягненні мети. Крім того, за рахунок умов гри опір учасників послаблюється, і активується внутрішня мотивація за рахунок ефектів поля (Lewin, n.d.).

Перевагою трансформаційних ігор є те, що вони захоплюють, підвищують рівень групового збудження, поряд з так званою ігровою відповідальністю, підвищують реактивність у ситуації гри (Myers, 2009).

Отже, дослідження наукової літератури дозволило нам зробити висновки, що для роботи психолога ігрова форма діяльності має переваги, тому що вона:

- допомагає у встановленні контакту з клієнтом; 
- сприяє зняттю бар'єрів спілкування;

- безпосередньо працює з підсвідомим;

- дозволяє усвідомити, відчути і вербалізувати актуальні, хвилюючі проблеми;

- здійснює пошук несподіваних рішень, поглядів та відкриттів;

- виробляє нові варіанти подолання проблем.

Для клієнта психологічна гра важлива, тому що це:

- метод навчання, який дозволяє краще розуміти себе і свої цінності, розібратися в своїх проблемах;

- допомога в досягненні важливої життєвої або професійної мети;

- спосіб зміцнення взаємин з оточенням (рідними, близькими, колегами тощо);

- можливість розібратися у міжоособистісних та внутрішньооособистісних конфліктах;

- шлях тренування психофізіологічної та психосоматичної діяльності, вироблення нових навичок;

- спосіб контакту з підсвідомим та порозуміння причин своїх життєвих перешкод;

- можливість релаксації, приємного проведення часу та альтернативного відпочинку в ігровому форматі.

В сучасній психології існує декілька теорій періодизації психічного розвитку людини в онтогенезі. Кожна 3 цих теорій $\epsilon$ цінною та знаходить своє певне відображення в теоретичних засадах розробленої методики "Му Dao".

На кожному етапі більш актуальними стають ти чи інші цінності особистості. Вони впливають на життєву спрямованість, професійну та сімейну орієнтацію, професійне зростання та інші мотиви, що формують особистість (Melnyk, 2017; Melnyk \& Stadnik, 2018a).

Зміст та особливості використання психологічної трансформаційної гри "Му Dаo" або "Мій шлях" (далі - "Му Dao") розкрито (Melnyk \& Stadnik, 2018b).

Стисло розглянемо основні методологічні, теоретичні та методичні положення цієї методики.

Методологія "Му Dao" $€$ складним переплетінням психологічних підходів, теорій та технік, серед яких:

- психоаналітичний підхід до аналізу особистості гравця через дослідження психологічних механізмів "Еgo"-захисту та використання психоаналітичних технік; 
- аналітичний підхід до аналізу комплексів та несвідомого через обрання та інтерпретації вибору ігрових фігур гравцями;

- трансактний аналіз (структурний аналіз, трансактний аналіз, аналіз гри, аналіз сценарію) до дослідження взаємодії гравців у спілкуванні, що супроводжується представленням їх позицій;

- гештальт підхід до інтерпретацій та обговорення картоккартин та карток-стимулів, які здійснюють учасники в процесі гри;

- індивідуальний підхід до аналізу життєвих цілей та стилю життя на різних вікових етапах (ігрових зонах) у гравців;

- діяльнісний та тілесно-орієнтований підхід до аналізу поведінки та невербальних дій гравців, які вони здійснюють під час грі.

Серед багатьох методологічних підходів та теорій, на які ми спирались у розробці “Му Dаo", особливо слід виокремити теорію діяльнісної періодизації. Відповідно до цієї теорії психологи традиційно виокремлюють періоди дитинства, підліткового, юнацького віку.

У розробленій нами методиці ми умовно поділили гру на три етапи:

1) дитинство, де провідним видом діяльності є гра;

2) підлітковий та юнацький вік, де провідним видом діяльності $\epsilon$ навчання;

3) період зрілості та похилого віку, де провідним видом діяльності є професійна діяльність.

Важливими $є$ вихідні положення та ключові принципи методики "My Dao":

- принцип нейтральності;

- принцип рівної позиції;

- принцип єдності рішення і дії.

Meта "My Dao": дослідження самооцінки та мотивації учасників, розкриття їх особистісних ресурсів для вирішення проблем і подальшого розвитку.

Цільова група “My Dao”: розрахована на клієнтів 3 досить широким віковим діапазоном - від молоді (3 17 років) до людей похилого віку, а також широким спектром глибинних особистісних проблем учасників. Може використовуватися для осіб у неклінічній та клінічній психотерапії.

Інструментарій "My Dao":

1) 12 фігурок, тварини-символи;

2) 108 карток-картин;

3) 36 карток-стимулів; 
4) ігровий кубик;

5) ігрове поле.

Хід гри "Му Dао" поділяється на три етапи: підготовчий, основний, заключний.

Підготовчий eman. Ведучий проводить інструктаж учасників, знайомить їх з правилами гри, метою гри, проводить жеребкування тощо.

Основний етап. Гравці по черзі кидають кубик, роблять хід на певну кількість пунктів. Беруть 3 певного стовпчика картку-картину та описують свої асоціації, котрі викликає у них ця картка, а також відповідають на питання ведучого і учасників, якщо такі є. Після відповіді гравці беруть картку-мотиватор та відповідають на питання ведучого.

Учасники проходять через всі три сектори: спочатку жовтий (гра), потім зелений (навчання) та червоний (праця). Вони роблять наступні ходи, при цьому описують асоціації отриманих карток-картин та отриманих/обраних карток-мотиваторів.

Заключний eman. Підбиття підсумків учасниками та ведучім. Учасники аналізують свої життєві здобутки, асоціюючи їх 3 накопиченими за гру картками.

Для перевірки ефективності трансформаційної психологічної гри "Му Dao" нами застосована методика діагностики ціннісних орієнтацій Ш. Шварца (адаптація В. Карандашева), що використовується для дослідження динаміки зміни цінностей у групах і особистості у зв'язку з її життєвими проблемами (Karandashev, 2004). В основі опитувальника лежить теорія, згідно якої всі цінності поділяються на суспільні (культурно-ціннісні орієнтації) та індивідуальні. Респонденту пропонувалося оцінити ступінь важливості кожної цінності як домінуючого принципу його життя у балах. Чим вищий бал, тим важливішою для нього $\epsilon$ ця цінність.

Наведемо коротке визначення типів ціннісних орієнтацій відповідно до їхньої центральної мети за Ш. Шварцем:

- влада - соціальний статус, домінування над людьми i ресурсами;

- досягнення - особистий успіх в відповідно до соціальних стандартів;

- гедонізм - насолода або чуттєве задоволення;

- стимуляція - хвилювання і новизна;

- самостійність - самостійність думки і дії;

- універсалізм - розуміння, терпимість і захист благополуччя всіх людей та природи; 
людей;

- доброта - збереження і підвищення добробуту близьких

- традиція - повага і відповідальність за культурні, релігійні звичаї та ідеї;

- конформність - стримування дій та мотивів, які можуть зашкодити іншим і не відповідають соціальним очікуванням;

- безпека - безпека, стабільність суспільства, відносин та самого себе.

Для дослідження ми обрали групу, яку складали клієнти до та після проходження психологічної трансформаційної гри "Му Daо" 134 особи, серед них 75 чоловіків (55.97\%) та 59 жінок (44.03\%) віком 17-35 років (учні старших класів, студенти, працівники). Контрольна група була в кількості 126 осіб, серед них 69 чоловіків (54.76\%) та 57 жінок (45.24\%) віком 18-30 років (переважно студенти вишів).

Внаслідок вивчення особливостей цінностей за методикою Ш. Шварца виявлено середні показники цінностей у балах між досліджуваною (до і після гри) і контрольною групами.

Найбільш вираженими в досліджуваній групі на рівні нормативних ідеалів особистості до гри є цінності доброти, гедонізму та комфортності. Ці показники характеризують особистість, для якої важливою є лояльність, поблажливість, задоволення, насолода життям, слухняність, самодисципліна, ввічливість, повага до батьків і старших. Після проходження гри ці показники знизились. В той же час, потрібно відзначити найбільш суттєву динаміку деяких показників в процесі гри. Відбулося збільшення показників безпеки 34.4 до 5.8 балів $(\mathrm{p}<0.05)$, що говорить про зростання ролі гармонії та стабільності. Також помітно зменшення ролі традиції 36.2 до 5.3 балів, універсалізму з 6.6 до 5.9 балів та гедонізму з 6.9 до 6.2 балів $(\mathrm{p}<0.05)$, що говорить про знецінення смиренності, прийняття своєї долі після участі в грі.

Для контрольної групи найбільш суттєвими бали такі цінності: доброта, конформність та самостійність, що відповідає таким якостям, як чесність, відповідальність, дружба, самодисципліна, ввічливість, самоконтроль і самоврядування.

На індивідуальному рівні в досліджуваній групі в процесі гри спостерігається збільшення гедонізму, влади та стимуляції, що свідчить про те, що для них збільшилась роль задоволення, успішності, амбітності, прагнення до новизни та глибоких переживань.

В той же час високі показники після гри універсалізму, гедонізму, самостійності та конформності свідчать про зростання розуміння, терпимості, насолоди життям, самоконтролю, 
самоврядування, самодисципліни та ввічливості. Індивідуальний рівень особистості контрольної групи теж характеризується високими показниками самостійності та універсалізму.

Отже, найбільша значущість впливу розробленої психологічної трансформаційної гри "Му Daо” на клієнта за методикою діагностики ціннісних орієнтацій Ш. Шварца спостерігається на рівні нормативних ідеалів (безпека, традиція, гедонізм та універсалізм), що свідчить про певну зміну їх у бік збільшення гармонії і стабільності, зменшення смиренності, прийняття своєї долі, задоволення, насолоди життям, розуміння i терпимості. На рівні індивідуальних пріоритетів спостерігається збільшення гедонізму, влади та стимуляції.

Таким чином, для психолога трансформаційна гра приваблива тому, що вона допомагає у встановленні контакту, безпосередньо працює 3 підсвідомим, дозволяє усвідомити, відчути і вербалізувати актуальні, хвилюючі проблеми та виробляє нові варіанти їх вирішення. В той же час для клієнта психологічна гра важлива тому, що дозволяє краще розуміти себе і свої цінності, розібратися в своїх проблемах, допомагає у досягненні важливої життєвої або професійної мети, зміцнює взаємини з оточенням, $є$ методом релаксації, приємного проведення часу та альтернативного відпочинку.

\section{Висновки:}

Розроблена психологічна трансформаційна гра "My Dao" спрямована на зміну самооцінки і мотивації учасників, розкриття їхніх особистісних ресурсів для вирішення проблем і подальшого розвитку. Ця методика $\epsilon$ достатньо універсальною за віковою категорією учасників і за можливістю вирішення психологічних проблем.

Найбільша значущість впливу розробленої психологічної трансформаційної гри “Му Dao" на клієнта за методикою діагностики ціннісних орієнтацій Ш. Шварца спостерігається на рівні нормативних ідеалів, таких як традиція, конформність, безпека, гедонізм та універсалізм, що свідчить про певну зміну їх у бік збільшення гармонії і стабільності, а також зменшення смиренності, прийняття своєї долі. На рівні індивідуальних пріоритетів спостерігається збільшення гедонізму, влади та стимуляції, що свідчить про зростання ролі задоволення, успішності, амбітності, прагнення до новизни та глибоких переживань. В той же час високі показники після гри універсалізму, гедонізму, самостійності та конформності вказують на зростання розуміння, терпимості, насолоди життям, самоконтролю, самоврядування, самодисципліни та ввічливості. Тоді як індивідуальний рівень особистості контрольної групи 
характеризується переважно відносно високими показниками самостійності та універсалізму.

Перспективними $\epsilon$ дослідження психологічної трансформаційної гри “Му Dao” серед осіб похилого віку та учасників 3 різними психологічними проблемами, а також іiі апробація в клінічній психотерапії.

\section{Conflicts of interests:}

The authors declare that there is no conflict of interests.

\section{Source of support:}

This research did not receive any outside funding or support.

\section{References}

Berne, E. (2016). Games people play: The psychology of human relationships. Penguin Life. (Reprinted from Games people play: The psychology of human relationships (1st ed.), by E. Berne, 1964, Grove Press). https://rrt2.neostrada.pl/mioduszewska/course_2643_reading_3.pdf

Cherevko, A. P. (2006). Igra: sushnost, funkcii i disfunkcii [Play: Essence, Function and Dysfunction]. Vologdinskie chtenija - Vologda Readings, 59, 43-45. https://cyberleninka.ru/article/n/igra-suschnostfunktsii-i-disfunktsii [in Russian]

Faerman, M. I. (2020). Transformacionnaja igra kak uchebnaja psihotehnologija [Transformational Play as Educational Psychotechnology]. In E. V. Bukshina (Ed.), Konsultativnaja psihologija: vyzovy praktiki - Counseling Psychology: Challenges of Practice (pp. 245-247). https://doi.org/10.24411/9999-055A-202000059 [in Russian]

Fink, E. (2016). Osnovnye fenomeny chelovecheskogo bytiya [The Basic Phenomena of Human Existence]. Kanon. https://www.koob.ru/fink/ [in Russian]

Frissen, V., Lammes, S., de Lange, M., de Mul, J., \& Raessens, J. (2015). Homo ludens 2.0: Play, media, and identity. In V. Frissen (Ed.), Playful Identities: The Ludification of Digital Media Cultures (pp. 950). Amsterdam University Press. https://doi.org/10.1515/9789048523030-001

Guzik, M. A. (2012) Igra kak fenomen kultury [Game as a Cultural Phenomenon]. Flinta. https://unotices.com/books-u/156745 [in Russian]

Heckhausen, H. (1977). Achievement motivation and its constructs: A cognitive model. Motivation and Emotion, 1, 283-329. 
https://doi.org/10.1007/BF00992538

Huizinga, J. (2016). Homo ludens: A study of the play-element in culture. Angelico Press. (Reprinted from Homo ludens: proeve eener bepaling van het spel-element der cultuur (1st ed.), by J. Huizinga, 1938 , The Beacon Press). https://bibliodarq.files.wordpress.com/2014/06/huizinga-j-homoludens.pdf

Karandashev, V. N. (2004). Metodika Shvarca dlja izuchenija cennostej lichnosti [Schwartz methodology for the study of values personality]. Rech. https://altairbook.com/go2/2173160.html [in Russian]

Lewin, K. (n.d.). Field theory in social science. Harper \& Brothers. https://ia802905.us.archive.org/4/items/in.ernet.dli.2015.138989/201

5.138989.Field-Theory-In-Social-Science-Selected-TheoreticalOaoers.pdf

Melnyk, Yu. B. (2004). Osoblyvosti formuvannia kultury zdorovia: model kultury zdorovia osobystosti uchnia [Features of the formation of a health culture: a model of the health culture of the learner's personality]. Pedagogics, Psychology, Medicalbiological Problems of Physical Training and Sports, 11, 37-46. [in Ukraininan] https://www.sportpedagogy.org.ua/html/Pedagogy/Pdf2004/PD2004-11.pdf\#page $=38$

Melnyk, Yu., \& Stadnik, A. (2018a). Mental health of a personality: Diagnostics and prevention of mental disorders. International Journal of Education and Science, 1(3-4), 50. https://doi.org/10.26697/ijes.2018.3-4.37

Melnyk, Yu., \& Stadnik, A. (2018b). Psykholohichna transformatsiina hra "My Dao" [Psychological transformation game "My Dao"]. KRPOCH.

https://doi.org/10.26697/ari.krpoch/melnyk.stadnik.1.2018

Melnyk, Yu. B., Stadnik, A. V., \& Pypenko, I. S. (2020). Resistance to post-traumatic stress reactions of vulnerable groups engaged in pandemic liquidation. International Journal of Science Annals, 3(1), 35-44 https://doi.org/10.26697/ijsa.2020.1.5

Melnyk, Yu. (2017). Study of trends of students' demand for the formation of competences by higher educational institutions. Science and Education, 5, 128-134. https://doi.org/10.24195/2414-4665-2017-522

Myers, D. G. (2009). Social psychology (10th ed.). The McGraw-Hill Companies. https://diasmumpuni.files.wordpress.com/2018/02/david_g_myers_social_psychology_10th_editionbookfi.pdf 
Nicholson, S. (2015). A RECIPE for meaningful gamification. In T. Reiners \& L. C. Wood (Eds.), Gamification in Education and Business (pp. 1-20). Springer. https://doi.org/10.1007/978-3-319-10208-5_1

\section{Information about the authors:}

Melnyk Yuriy Borysovych - https://orcid.org/0000-0002-8527-4638; Doctor of Philosophy in Pedagogy, Associate Professor; Founder and Chairman of the Board, Kharkiv Regional Public Organization "Culture of Health" (KRPOCH); Director, Scientific Research Institute KRPOCH, Kharkiv, Ukraine.

Research interests: education, psychology, psychological technology, culture of health.

Stadnik Anatoliy Volodymyrovych - https://orcid.org/0000-0002-14724224; Doctor of Philosophy in Medicine, Associate Professor, Kharkiv National University of Internal Affairs; Director, Social-Psychological Center KRPOCH, Kharkiv, Ukraine.

Research interests: education, psychology, medicine, psychiatry.

\section{Cite this article as:}

Melnyk, Yu. B., \& Stadnik, A. V. (2021). Psykholohichna transformatsiina hra "My Dao" yak efektyvnyi metod roboty psykholoha [Psychological transformation game "My Dao" as an effective method of psychologist practice]. In Yu. B. Melnyk, \& L. M. Georgieva (Eds.), Current Issues of Education and Science. 9th International Conference, CIES-2021, Riga, Latvia - Kharkiv, Ukraine, November 10-13, 2021, Conference $\begin{array}{lll}\text { proceedings (pp. 52-65). KRPOCH. } & \end{array}$ https://doi.org/10.26697/9786177089147.2021.07 [in Ukrainian]

\section{Copyright information:}
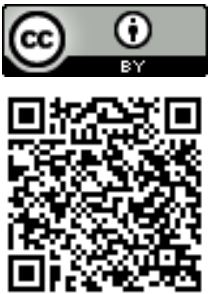

The published paper are licensed under a Creative Commons "Attribution" 4.0 Worldwide

The electronic version of this article is complete. Full or partial reproduction of article is allowed, citing to the source, author(s) and DOI. An electronic copy of the Conference proceedings in open access is available via the KRPOCH Publishing website https://publisher.culturehealth.org 